\title{
Antibody Affinity Against 2009 A/H1N1 Influenza and Pandemrix Vaccine Nucleoproteins Differs Between Childhood Narcolepsy Patients and Controls
}

\author{
Alexander Lind, ${ }^{1}$ Eva Freyhult, Anita Ramelius,, Tomas Olsson, ${ }^{3}$ Lisen Arnheim-Dahlström, \\ Favelle Lamb, Mohsen Khademi, ${ }^{3}$ Aditya Ambati, Markus Maeurer, Izaura Lima Bomfim, \\ Katharina Fink, ${ }^{3,7}$ Malin Fex, ${ }^{1}$ Carina Törn, ${ }^{1}$ Helena Elding Larsson, ${ }^{1}$ and Åke Lernmark ${ }^{1}$
}

\begin{abstract}
Increased narcolepsy incidence was observed in Sweden following the 2009 influenza vaccination with Pandemrix ${ }^{\circledR}$. A substitution of the 2009 nucleoprotein for the 1934 variant has been implicated in narcolepsy development. The aims were to determine (a) antibody levels toward wild-type A/H1N1-2009[A/California/04/2009(H1N1)] (NPCA2009) and Pandemrix-[A/Puerto Rico/8/1934(H1N1)] (NP-PR1934) nucleoproteins in 43 patients and 64 agematched controls; (b) antibody affinity in reciprocal competitive assays in 11 childhood narcolepsy patients compared with 21 age-matched controls; and (c) antibody levels toward wild-type A/H1N1-2009[A/California/04/2009(H1N1)] (H1N1 NS1), not a component of the Pandemrix vaccine. In vitro transcribed and translated ${ }^{35} \mathrm{~S}$-methionine-labeled H1N1 influenza A virus proteins were used in radiobinding reciprocal competition assays to estimate antibody levels and affinity $(\mathrm{Kd})$. Childhood patients had higher NP-CA2009 $(p=0.0339)$ and NP-PR1934 $(p=0.0246)$ antibody levels compared with age-matched controls. These childhood controls had lower NP-CA2009 $(p=0.0221)$ and NPPR1934 ( $p=0.00619)$ antibodies compared with controls 13 years or older. In contrast, in patients 13 years or older, the levels of NP-PR1934 ( $p=0.279)$ and NP-CA2009 $(p=0.0644)$ antibodies did not differ from the older controls. Childhood antibody affinity (Kd) against NP-CA2009 was comparable between controls $(68 \mathrm{ng} / \mathrm{mL})$ and patients $(74 \mathrm{ng} / \mathrm{mL} ; p=0.21$ ) with NP-CA2009 and NP-PR1934 displacement (controls: $165 \mathrm{ng} / \mathrm{mL}$; patients: $199 \mathrm{ng} / \mathrm{mL}$; $p=0.48$ ). In contrast, antibody affinity against NP-PR1934 was higher in controls with either NP-PR1934 (controls: $9 \mathrm{ng} / \mathrm{mL}$; patients: $20 \mathrm{ng} / \mathrm{mL} ; p=0.0031$ ) or NP-CA2009 (controls: $14 \mathrm{ng} / \mathrm{mL}$; patients: $23 \mathrm{ng} / \mathrm{mL} ; p=0.0048$ ). A/ H1N1-NS1 antibodies were detected in 0/43 of the narcolepsy patients compared with $3 / 64$ (4.7\%) controls $(p=0.272)$. Similarly, none (0/11) of the childhood patients and 1/21 (4.8\%) of the childhood controls had A/H1N1NS1 antibodies. The higher antibody affinities against NP-PR1934 in controls suggest better protection against wildtype virus. In contrast, the reduced NP-PR1934 antibody affinities among childhood narcolepsy patients suggest poor protection from the wild-type $\mathrm{A} / \mathrm{H} 1 \mathrm{~N} 1$ virus and possibly increased risk for viral damage.
\end{abstract}

Keywords: radiobinding assay, Pandemrix-vaccination, A/H1N1 pandemic, vaccine-related-adverse-reactions

\section{Introduction}

$\mathbf{N}$ ARCOLEPSY TYPE 1 is a chronic neurological disorder caused by loss of neuropeptide hypocretin (11) producing cells located in the lateral hypothalamic area (49) and characterized by excessive daytime sleepiness, disrupted night sleep, sleep paralysis, and hypnagogic hallucinations (26). Cataplexy, episodes of loss of voluntary muscle tone in response to strong emotions, is a pathognomonic sign for narcolepsy type $1(9,10)$.

A strong genetic predisposition for narcolepsy type 1 with $75-98 \%$ of all patients associated with the human leukocyte

\footnotetext{
${ }^{1}$ Department of Clinical Sciences, Lund University/Clinical Research Center (CRC), Skåne University Hospital SUS, Malmö, Sweden. ${ }^{2}$ Department of Medical Sciences, National Bioinformatics Infrastructure Sweden, Science for Life Laboratory, Uppsala University, Uppsala, Sweden.

${ }^{3}$ Department of Clinical Neuroscience, Karolinska Institutet, Stockholm, Sweden.

Departments of ${ }^{4}$ Medical Epidemiology and Biostatistics and ${ }^{5}$ Medicine, Karolinska Institutet, Stockholm, Sweden.

${ }^{6}$ TIM, LabMed, Karolinska Institutet and CAST, Karolinska University Hospital, Stockholm, Sweden.

${ }^{7}$ Department of Neurology, Karolinska University Hospital, Stockholm, Sweden.
} 
antigen $(H L A)$ allele $D Q B 1 * 06: 02(22,33,46)$ suggests an autoimmune pathogenesis as an explanation for the highly specific hypocretin cell degeneration (38). A weak concordance rate of around $25 \%$ for monozygotic twins for narcolepsy type 1 indicates an important role for environmental stimulus (32). Infectious agents, including streptococcus $(5,6)$ and $\mathrm{H} 1 \mathrm{~N} 1$ influenza A virus $(15,48)$, have been suggested as triggers.

Increased incidence of narcolepsy was initially associated with Pandemrix ${ }^{\circledR}$ vaccination following the 2009 influenza pandemic not only in Finland (37) and Sweden $(40,45)$ but later also reported from other European countries $(8,18,34)$. In contrast, the incidence of narcolepsy in China was increased in conjunction with the 2009 H1N1 pandemic $(14,15)$. It was suggested that idiopathic narcolepsy differs from vaccine-associated narcolepsy (45) and that there are differences in predisposing HLA genes before, compared with after, the 2009 influenza pandemic (13).

In a previous investigation, we observed that levels of $\mathrm{A} /$ H1N1 2009 HA (also present in the vaccine) antibodies were increased among the childhood patients compared with agematched controls (27). In the present study, we wanted to test levels of antibodies against nucleoproteins and nonstructural proteins, which were either present or absent in Pandemrix.

It is hypothesized that the humoral immune response toward influenza nucleo- and nonstructural proteins differs among vaccine-associated narcolepsy patients compared with vaccinated healthy subjects. The aims were to determine (a) antibody levels toward wild-type A/H1N1 2009 nucleoprotein [A/ California/04/2009(H1N1)] and Pandemrix nucleoprotein [A/ Puerto Rico/8/1934(H1N1)] in 43 patients and 64 age-matched controls; (b) antibody affinity and specificity in childhood patients with narcolepsy $(n=11)$ compared with childhood controls $(n=21)$ in a reciprocal competitive assay by testing the binding of ${ }^{35}$ S-NP1934 and ${ }^{35}$ S-NP2009 with both nonlabeled NP-PR1934 and NP-CA2009 proteins; and (c) antibody levels against the nonstructural protein NS1 present in the A/H1N1 2009 virus, but not in the Pandemrix vaccine (31).

\section{Methods}

\section{Study populations}

Serum samples were obtained from 43 Swedish patients diagnosed with narcolepsy following multiple sleep latency test during the period between January 1, 2009, and December 31,2010 . The Pandemrix vaccine had been given to all 43 individuals (Table 1) and blood samples were obtained 1.5-2 years after vaccination, as previously described (27). Also included were 64 Pandemrix-vaccinated healthy controls randomly selected from the Swedish population register and asked to participate by mail. Healthy controls were matched to patients based on age and gender in a 1:2 ratio (Table 1). The identification of patients and controls, including the presence or absence of $H L A D Q B 1^{*} 06: 02$, is given elsewhere $(25,27)$.

\section{Cloning A/H1N1 nucleoprotein and nonstructural protein complementary DNA}

The influenza A virus [A/California/04/2009(H1N1)] segment 5' nucleocapsid protein (NP) gene (GenBank accession FJ966083.1), influenza A virus [A/Puerto Rico/8/1934(H1N1)] NP gene (GenBank accession CY009447.1), and influenza A
Table 1. Characteristics of Subjects

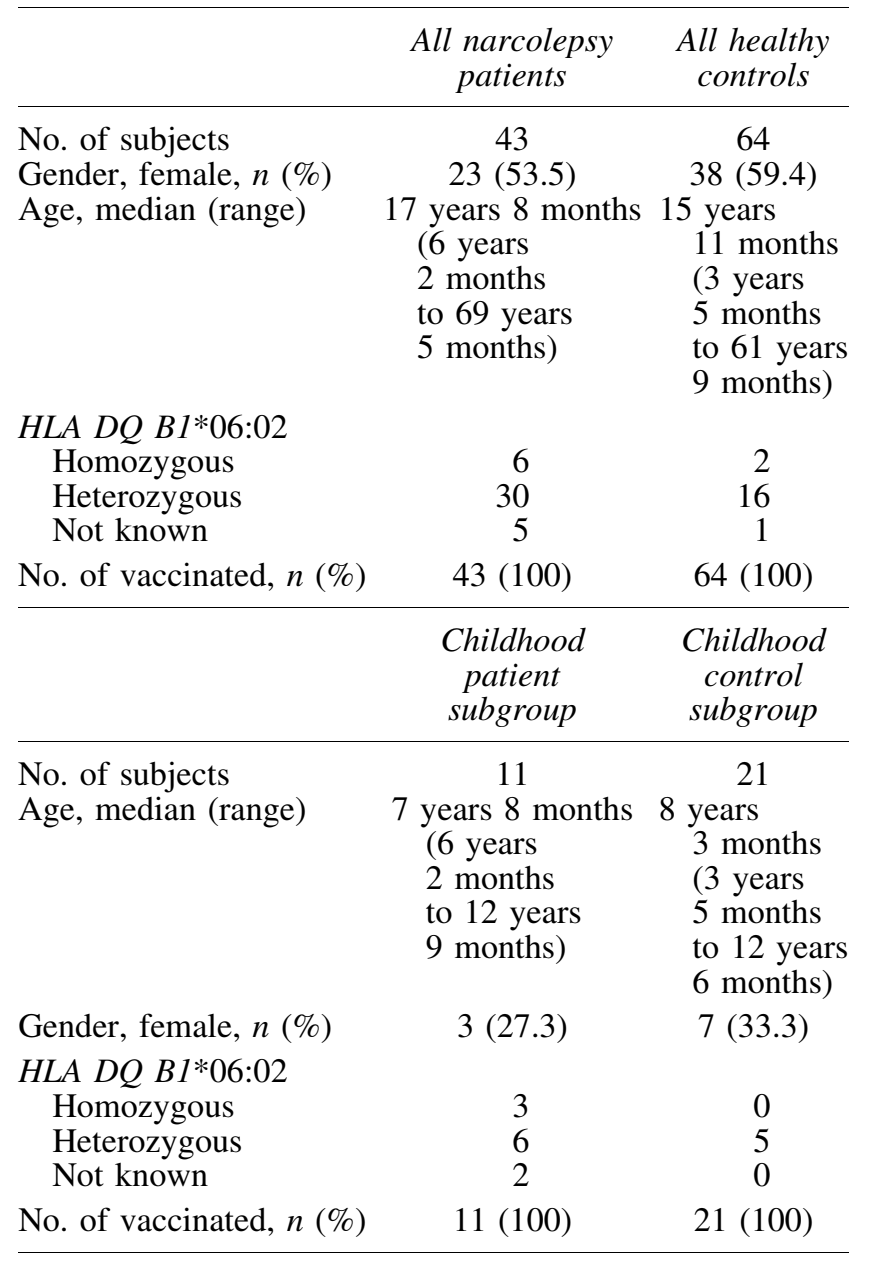

Ages correspond to October 2009, which was the start of the Swedish Pandemrix ${ }^{\circledR}$ vaccination campaign.

$H L A$, human leukocyte antigen.

virus [A/California/04/2009(H1N1)] nonstructural protein 1 (GenBank accession ACP41110.1) were synthesized and cloned into the pJ204 vector by DNA2.0 (San Diego, CA).

Recombinant genes were designed with flanking restriction enzyme sites Xhol and Xbal (NP CA2009, NP PR1934) or KpnI and Xbal (H1N1 NS1) (FastDigest ${ }^{\text {TM }}$; Fermentas, Helsingborg, Sweden). Kozak encoding sequence GCCACC was inserted between the start codon and the $5^{\prime}$ restriction site to increase initiation of translation. The protein encoding sequences were cut from the original vector, subcloned into the pTNT vector (Promega, Southampton, United Kingdom), and transformed into Escherichia coli DH5 $(\alpha)$ (NP PR1934 and H1N1 NS1) or Invitrogen one-shot inv110 (NP CA2009) competent cells. Complementary DNA (cDNA) plasmid extraction using the QIAprep Spin Miniprep kit (Qiagen, Solna, Sweden) was followed by sequence verification by GATC Biotech AG (Konstanz, Germany).

\section{Generation of ${ }^{35} \mathrm{~S}-\mathrm{A} / \mathrm{H} 1 \mathrm{~N} 1$ proteins by in vitro transcription translation}

Radiolabeled A/H1N1 proteins were synthesized using the TNT SP6-coupled reticulocyte lysate system (Promega) 
for in vitro transcription translation. cDNA pTNT-A/H1N1 protein plasmids $(1 \mu \mathrm{g} / \mu \mathrm{L}$, final concentration $0.02 \mu \mathrm{g} / \mu \mathrm{L})$ were mixed with ${ }^{35} \mathrm{~S}$-methionine (PerkinElmer Life and Analytical Sciences, Brussels, Belgium) and the TNT SP6coupled reticulocyte lysate system. Incubation was carried out for $90 \mathrm{~min}$ at $30^{\circ} \mathrm{C}$, followed by removal of the unincorporated label using Nap-5 columns (GE Healthcare BioSciences, Uppsala, Sweden). The mean incorporation rate of the radioactive label was $39 \%, 49 \%$, and $55 \%$ for NS1 CA2009, NP CA2009, and NP PR1934, respectively. Both nucleoproteins contained 498 amino acids with $91.6 \%$ shared homology (456/498 amino acids, Supplementary Fig. S1A; Supplementary Data are available online at www.liebertpub .com/vim).

\section{Influenza ${ }^{35} \mathrm{~S}$ A/H1N1 nucleoprotein radiobinding antibody assay}

Radiolabeled A/H1N1 nucleoproteins obtained through in vitro transcription translation were used as antigens to detect antibodies in $2.5 \mu \mathrm{L}$ serum in duplicate (12). A total of $60 \mu \mathrm{L}$ of radiolabeled protein, corresponding to 24,000 counts per minute $(\mathrm{cpm})$ in total $(400 \mathrm{cpm} / \mu \mathrm{L})$, was incubated overnight diluted in Tris-buffered saline $(\mathrm{pH} 7.4)$ supplemented with $0.15 \%$ (v/v) Tween $20,0.1 \%$ (w/v) bovine serum albumin, and 1\% (v/v) Triton X-100 (TBST). Antibody-bound proteins were separated from free ${ }^{35} \mathrm{~S}$ labeled A/H1N1A nucleoproteins using protein ASepharose (Zymed Laboratories, Inc., San Francisco, CA) after transfer to filtration plates (Millipore, Solna, Sweden). The plates were washed using TBST and Super Mix scintillation cocktail (PerkinElmer) was added and the antibodybound ${ }^{35} \mathrm{~S}$-labeled $\mathrm{A} / \mathrm{H} 1 \mathrm{~N} 1$ nucleoproteins were counted in a Wallac Microbeta Trilux beta counter (PerkinElmer).

A serum sample with high $\mathrm{A} / \mathrm{H} 1 \mathrm{~N} 1$ nucleoprotein antibody level was used as an in-house standard, diluted in seven steps starting with 1:12,800, and used to express A/ H1N1 nucleoprotein antibody levels in arbitrary $\mathrm{U} / \mathrm{mL}$. A total of $250 \mathrm{U} / \mathrm{mL}$ of the in-house standard serum corresponded to $2.5 \mu \mathrm{g} / \mathrm{mL}$ in the ${ }^{35} \mathrm{~S}-\mathrm{NP}$ PR1934 assay and $4.6 \mu \mathrm{g} / \mathrm{mL}$ in the ${ }^{35} \mathrm{~S}-\mathrm{NP}$ CA2009 assay of commercial rabbit polyclonal antibody against recombinant $\mathrm{A} / \mathrm{H} 1 \mathrm{~N} 1$ Puerto Rico/8/34/Mount Sinai nucleoprotein (Sino Biological, Inc., Beijing, China; Supplementary Fig. S1B).

Initial analyses of all serum samples resulted in values higher than the maximum of the standard curve. All samples were therefore diluted to $1 / 100$. The standard curve was linear up to about $200 \mathrm{U} / \mathrm{mL}$; therefore, all samples with higher $\mathrm{A} /$ $\mathrm{H} 1 \mathrm{~N} 1$ nucleoprotein antibody levels than $180 \mathrm{U} / \mathrm{mL}$ at dilution $1 / 100$ were titrated in additional steps; $1 / 200,1 / 400$, and $1 / 800$ to fit the standard curve. Duplicate samples with a coefficient of variation $(\mathrm{CV}) \geq 12 \%$ were reassayed. The intraassay CV was $2.9 \%$ and $3.3 \%$ for NP CA2009 and NP PR1934 antibody analyses, respectively. Two control samples were included in all assays and the interassay CV was $11 \%$ and $9 \%$ for NP CA2009 and NP PR1934, respectively.

\section{Competitive radiobinding assay using recombinant influenza $A / H 1 N 1$ nucleoproteins}

Using a reciprocal permutation strategy as previously described (44), serum samples from selected patients and controls $(<13$ years) were incubated with previously described in vitro produced ${ }^{35} \mathrm{~S}$-radiolabeled nucleoproteins $\left({ }^{35} \mathrm{~S}-\mathrm{NP}\right.$ CA2009 or ${ }^{35} \mathrm{~S}-\mathrm{NP}$ PR1934) in combination with either nonlabeled recombinant influenza A virus H1N1 (A/Puerto Rico/8/34/Mount Sinai) nucleoprotein (Sino Biological, Inc.) or influenza A virus H1N1 (A/California/07/09) nucleoprotein (Sino Biological, Inc.).

Antibody analyses were performed as previously described (44); $30 \mu \mathrm{L}$ of ${ }^{35} \mathrm{~S}-\mathrm{NP}$ (NP PR1934 or NP CA2009) diluted to $850 \mathrm{cpm} / \mu \mathrm{L}$ was mixed with $30 \mu \mathrm{L}$ of commercially obtained nonlabeled nucleoproteins (final concentrations: $0,0.0005,0.005,0.005,0.5$, and $5 \mu \mathrm{g} / \mathrm{mL})$. The intraassay coefficients of variation were determined as $6.4 \%$ and $5.1 \%$ for ${ }^{35}$ S-NP CA2009 displacement and as $7.3 \%$ and $3.8 \%$ for ${ }^{35}$ S-NP PR1934 displacement, respectively. ${ }^{35} \mathrm{~S}-$ NP specificity was tested in three high-titer serum samples through displacement with nonlabeled recombinant HA2009 (Sino Biological, Inc.; Supplementary Fig. S1C, D).

\section{Influenza ${ }^{35} \mathrm{~S}$ A/H1N1 nonstructural protein (H1N1 NS1) radiobinding antibody assay}

Antibodies against A/H1N1 NS1 were determined in a radiobinding assay as described for the A/H1N1 NPs. The cutoff for H1N1 NS1 antibodies was 1,525 U/mL at the 97.25th percentile in serum from 200 healthy blood donors ascertained in 2008 (21) (Supplementary Fig. S2). A serum sample with high A/H1N1 NS1 antibody titer was diluted 1:1,600-1:25 $(1,000 \mathrm{U} / \mathrm{mL})$ as an in-house standard to express A/H1N1 NS1 antibody levels in arbitrary $\mathrm{U} / \mathrm{mL}$. The intra-assay $\mathrm{CV}$ was $5 \%$. The interassay $\mathrm{CV}$ for three in-house controls included in each assay was $14 \%$.

\section{HLA DQ typing}

HLA $D Q B 1^{* 06: 02}$ was identified with the linked SNP rs9271366 (GG-homozygous $D Q B 1 * 0602$, AG-heterozygous, AA-non- $D Q B 1 * 06: 02)$ using TaqMan allelic discrimination assays, as outlined elsewhere $(17,28)$.

\section{Ethical considerations}

The study was approved by the Regional Ethics Review Board in Stockholm. All study participants or parental guardian(s) gave their written consent.

\section{Statistical analyses}

Median levels between groups were compared using MannWhitney's U test and Wilcoxon signed-rank test (paired comparisons). Associations between two continuous variables were measured using Spearman's $\rho$ (rho). A four-parameter log-logistic function was fitted to the displacement data for each individual and displacement type using the drc package in $R(42)$. The fitted function is $y=D+(A-D) /\left(1-(x / C)^{\wedge} D\right)$, where $\mathrm{y}$ is the binding $(\%)$ and $\mathrm{x}$ the concentration. The parameters $\mathrm{A}, \mathrm{B}, \mathrm{C}$, and $\mathrm{D}$ were constrained to positive values during optimization. Maximal displacement percentage was computed as $100-\mathrm{D}$, where $\mathrm{D}$ is the parameter that represents the minimal binding value. The affinity was calculated as halfmaximal binding, Kd50, and expressed in $\mathrm{ng} / \mathrm{mL}$.

The significance threshold is set to 0.05 for the initial tests on antibody levels and antibody levels in association with age. For the following tests on displacement statistics (affinity and maximal displacement) as well as the tests of 
association between antibody levels and antibody levels and affinity, we use a lower significance threshold of 0.005 , motivated by the multiple tests performed.

\section{Results}

\section{A/H1N1 nucleoprotein antibodies}

Binding of $\mathrm{A} / \mathrm{H} 1 \mathrm{~N} 1$ antibodies did not differ between narcolepsy patients and controls. Median antibody binding levels toward influenza A virus [A/California/04/2009(H1N1)] nucleoprotein (NP-CA2009) in serum samples from the 43 narcolepsy patients were $12,697 \mathrm{U} / \mathrm{mL}$ compared with $13,215 \mathrm{U} /$ $\mathrm{mL}$ in 64 matched healthy controls $(p=0.6$, Fig. 1$)$. The median antibody binding levels for influenza A virus [A/ Puerto Rico/8/1934(H1N1)] nucleoprotein (NP-PR1934) were $15,709 \mathrm{U} / \mathrm{mL}$ for the patients compared with $16,753 \mathrm{U} /$ $\mathrm{mL}$ for controls ( $p=0.896$, Fig. 1).

\section{A/H1N1 nucleoprotein antibodies in relation to age}

The levels of NP antibodies in the patients tended to decrease with increasing age (NP-CA2009: $\rho=-0.280$, $p=0.069$; NP-PR1934: $\rho=-0.271, p=0.079)$ in contrast to the controls where the levels increased with increasing age for NP-PR1934 $(\rho=0.280, p=0.025)$, but not for NPCA2009 $(\rho=0.206, p=0.102$, Fig. 2A). A permutation test, adopted to investigate if such a large difference in $\rho$ between the groups was to be expected by chance, showed that the opposite relationship was unlikely to occur by chance for both NP-CA2009 $(p=0.0153)$ and NP-PR1934 $(p=0.0058)$.

To further study the differences between younger and older individuals, both patients and controls were divided into groups based on age in October 2009 when the Swedish Pandemrix vaccination campaign was initiated: childhood patients $(n=11)$, childhood controls $(n=21)$, older patients ( $\geq 13$ years: $n=32$ ), and older controls ( $\geq 13$ years: $n=43$ ), respectively. The decision to compare subjects older and younger than 13 years was motivated by our previous study (27) in combination with the suggestion that Pandemrix vaccination might have induced younger age onset compared with idiopathic narcolepsy (45).

Median antibody levels were higher in the childhood patients compared with the childhood controls for both NPCA2009 $(p=0.0339)$ and NP-PR1934 $(p=0.0246$, Table 2). Median antibody levels among the older patients compared with their controls were comparable for NPCA2009 $(p=0.279)$ and NP-PR1934 $(p=0.0644$, Table 2 and Fig. 2B).

The childhood patients did not differ from the older patients, neither in antibody levels against NP-CA2009 $(p=0.219)$ nor against NP-PR1934 ( $p=0.0981$, Table 2$)$. In contrast, the childhood controls compared with older controls had lower antibody levels against both NP-CA2009 $(p=0.0221)$ and NPPR1934 ( $p=0.00619$, Table 2 and Fig. 2B).

\section{A/H1N1 nucleoprotein displacement}

We next determined antibody affinity toward both NPCA2009 and NP-PR1934 in reciprocal permutation competitive assays with serum samples from childhood narcolepsy patients $(<13$ years of age; age range $7-12$ years, $n=11)$ and age-matched controls ( $<13$ years of age, age range $3-12$ years, $n=21$, Fig. 3A). All samples were diluted to $50 \%$ of maximal binding, equivalent to $\sim 125 \mathrm{U} / \mathrm{mL}$ (Supplementary Table S1). The dilutions were, however, not exactly to $125 \mathrm{U} /$ $\mathrm{mL}$, although they did not differ between patients and controls for NP-CA2009 $(122 \mathrm{U} / \mathrm{mL}$ range $69-188 \mathrm{U} / \mathrm{mL}$ to $98 \mathrm{U} / \mathrm{mL}$ range $14-182 \mathrm{U} / \mathrm{mL}, p=0.133)$ or NP-PR1934 $(130 \mathrm{U} / \mathrm{mL}$ range $77-186 \mathrm{U} / \mathrm{mL}$ to $114 \mathrm{U} / \mathrm{mL}$ range $21-181 \mathrm{U} / \mathrm{mL}, p=$ 0.123, Supplementary Table S1).

The levels (U/mL) for NP-CA2009 and NP-PR1934 correlate strongly $(\rho=0.904, p<4.0 \mathrm{e}-08)$. The NP-PR1934 values were generally higher than the NP-CA2009 values
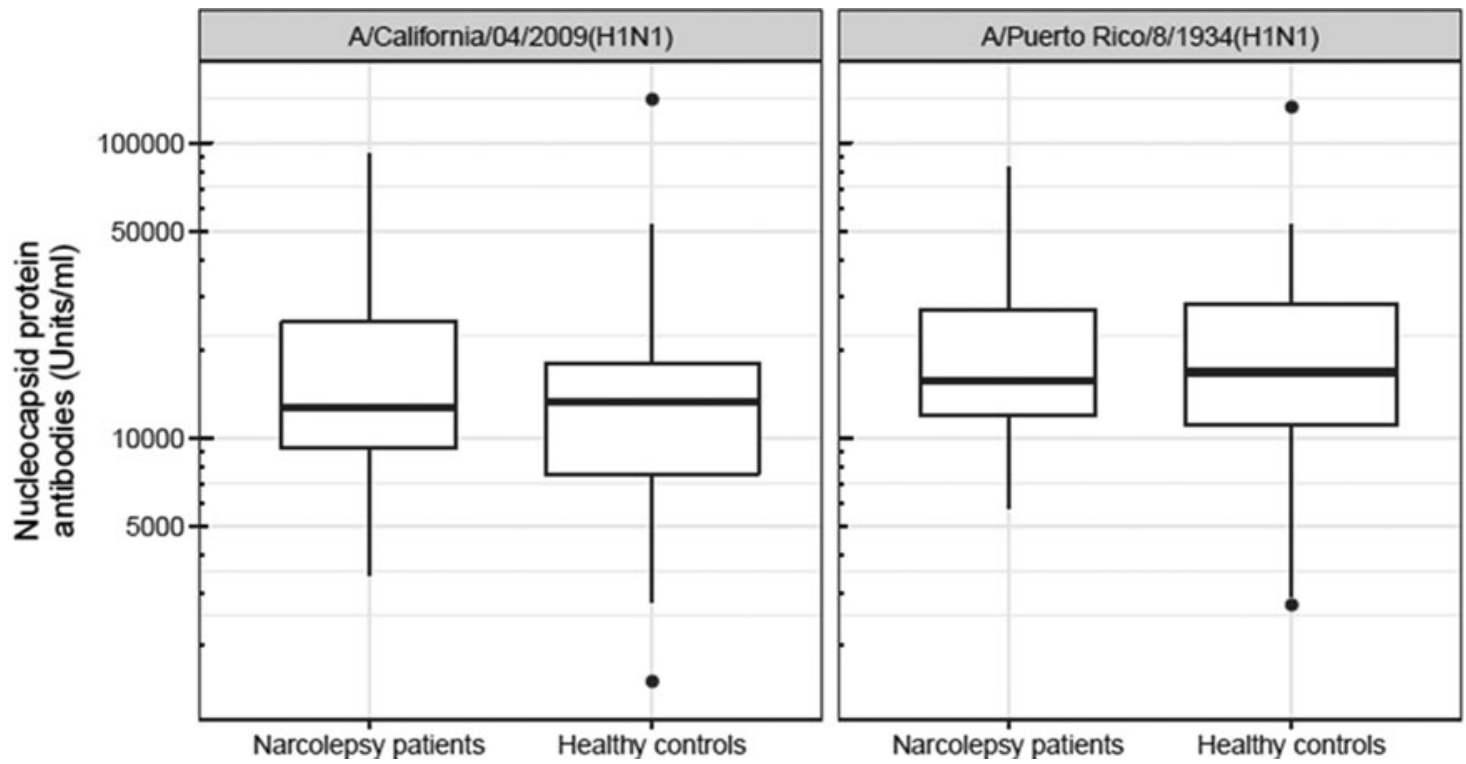

FIG. 1. Nucleoprotein antibody levels. Median levels (-) for influenza A virus [A/California/04/2009(H1N1)] nucleoprotein antibody were $12,697(3,451-91,389) \mathrm{U} / \mathrm{mL}$ and 13,215 $(1,497-139,816) \mathrm{U} / \mathrm{mL}$ for patients and controls, respectively $(p=0.6)$. Median levels (-) for influenza A virus [A/Puerto Rico/8/1934(H1N1)] nucleoprotein antibody among narcolepsy patients and healthy controls were $15,709(5,763-82,571) \mathrm{U} / \mathrm{mL}$ and $16,753(2,726-132,392) \mathrm{U} / \mathrm{mL}$, respectively $(p=0.896)$. 
A
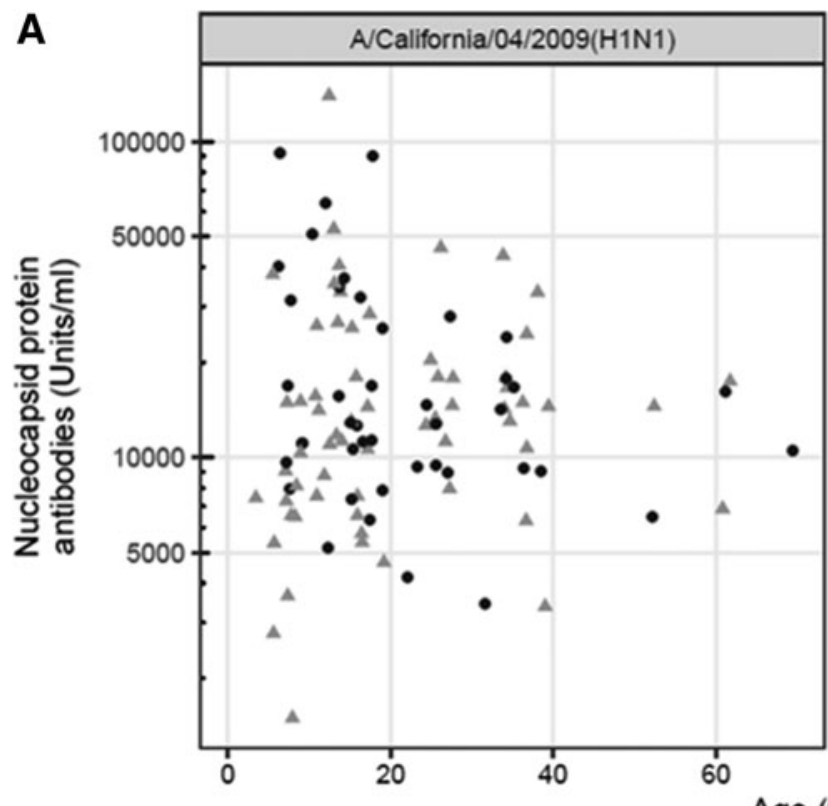

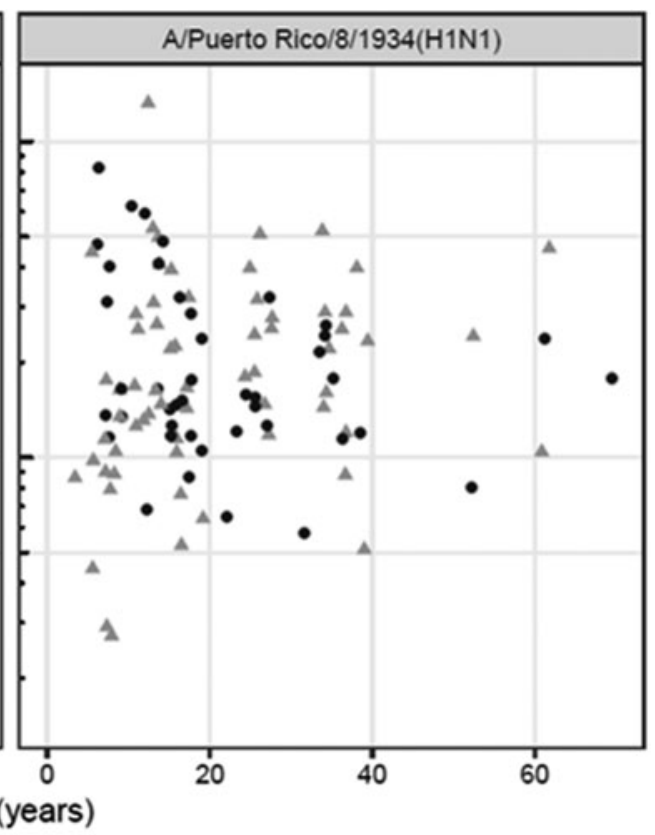

B

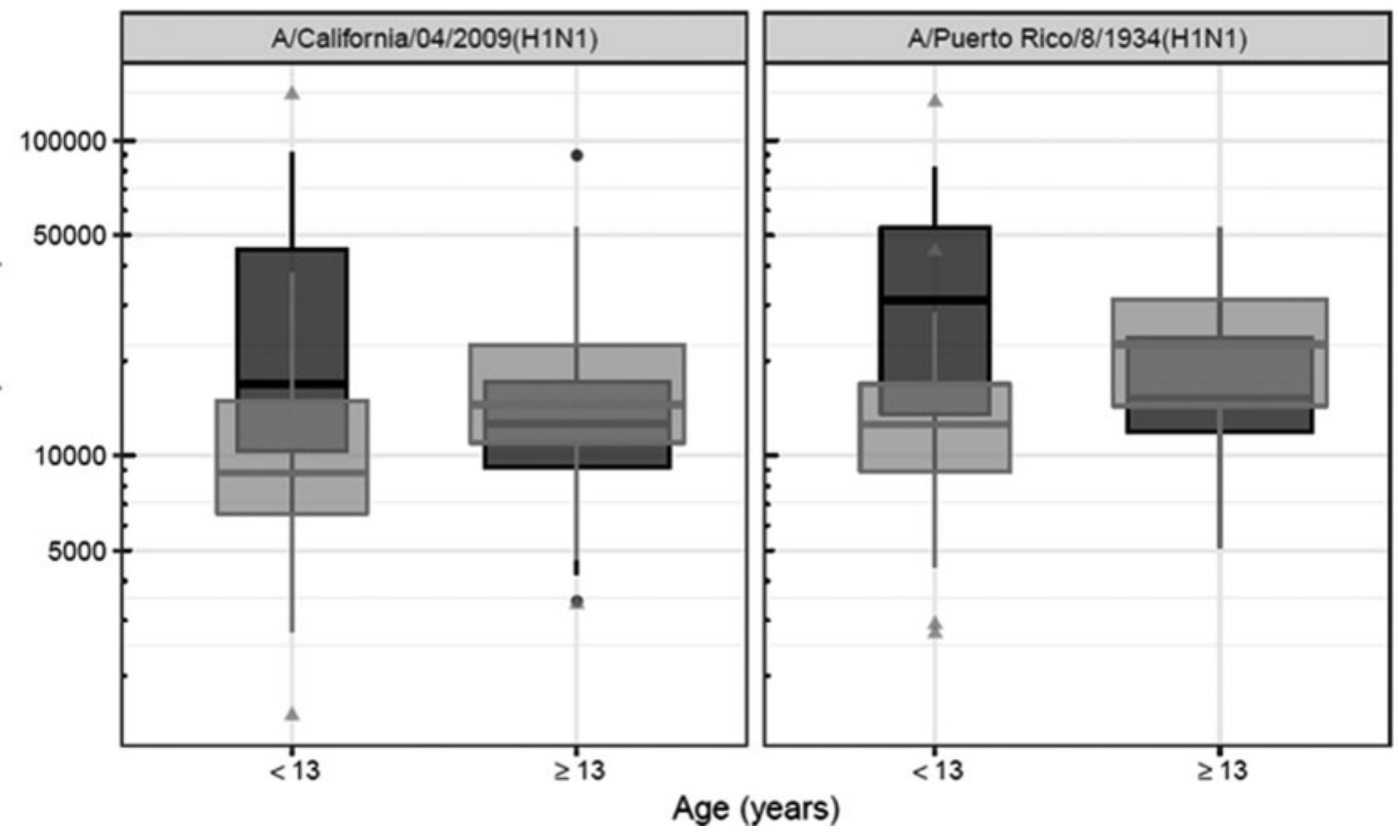

FIG. 2. (A) Association between nucleoprotein antibody binding levels and age. Healthy controls are shown as gray triangles and narcolepsy patients as black circles. The sign of the association was negative for patients (NP-CA2009: $\rho=-0.28, p=0.069$; NP-PR1934: $\rho=-0.27, p=0.079$ ), but the association was positive for controls (NP-CA2009: $\rho=0.206, p=0.102$; NP-PR1934: $\rho=0.280, p=0.025$ ). (B) Antibody levels per age group are illustrated as $<13$ and $\geq 13$ years for patients (dark gray) and controls (light gray), respectively. Antibody levels for the childhood patients $(n=11)$ were higher compared with childhood controls $(n=21)$ (NP-CA2009: 16,860-8,770 U/mL, $p=0.0339$; NP-PR1934: 31,099-12,563 U/mL, $p=0.0246)$. Childhood controls differed from the older controls $(n=43)$ (NP-CA2009: 8,770-14,502 U/mL, $p=0.0221$; NP-PR1934: $12,563-22,510 \mathrm{U} / \mathrm{mL}$, $p=0.00619)$. The older patients did not differ compared with the older among the controls for NP-CA2009 or NP-PR1934 antibody (NP-CA2009: 12,617-14,502 U/mL, $p=0.279$; NP-PR1934: 15,266-22,510 U/mL, $p=0.0644$ ). NP, nucleocapsid protein.

$(p=1.47 \mathrm{e}-04)$. The coefficients of variation for the three endpoint measurements were $11.58 \%$ and $11.63 \%$ for NP-CA2009 and NP-PR1934, respectively. The variable endpoint levels within patients and controls, as well as between the two groups, are illustrated in Figure $3 \mathrm{~A}$ after correcting the levels at $50 \%$ binding with the different degrees of dilution between the samples (Fig. 3A).
Maximal displacement. After dilution of all samples to about 50\% binding, the maximal displacement (\%) for NPCA2009 did not differ when using nonlabeled NP-CA2009 $(90.3 \%)$ or nonlabeled NP-PR1934 $(95.0 \%)$, neither in the patient serum sample $(p=0.15)$ nor in the controls (nonlabeled NP-CA2009: 90.7\%; nonlabeled NP-PR1934: 95.6\%, $p=0.01$, Table 3 and Fig. 3B). Maximal displacement (\%) of ${ }^{35}$ S- NPPR1934 in the patients was greater when using nonlabeled 
Table 2. Nucleoprotein Antibody Levels

\begin{tabular}{|c|c|c|c|c|c|}
\hline & Narcolepsy patients & Healthy controls & $\mathrm{p}^{\mathrm{a}}$ & $\mathrm{p}^{\mathrm{b}}$ & $\mathrm{p}^{\mathrm{c}}$ \\
\hline CA2009 $<13$ & $16,860(5,147-91,389) n=11$ & $8,870(1,497-139,816) n=21$ & 0.0339 & 0.219 & 0.0221 \\
\hline $\mathrm{CA} 2009 \geq 13$ & $12,617(3,451-89,645) n=32$ & $14,502(3,373-52,893) n=43$ & 0.279 & & \\
\hline PR1934<13 & $31,099(6,816-82,571) n=11$ & $12,563(2,726-132,392) n=21$ & 0.0246 & 0.0981 & 0.00619 \\
\hline PR1934 $\geq 13$ & $15,263(5,763-48,191) n=32$ & $22,510(5,114-53,163) n=43$ & 0.0644 & & \\
\hline
\end{tabular}

Median and range of antibody levels for patients and controls within the two age groups, $<13$ and $\geq 13$ years of age.

The three $p$-value columns present (unadjusted) $p$-values from the following tests: ${ }^{a}$ Mann-Whitney's U test comparing median values between patients and controls within the age groups, ' ${ }^{\mathrm{b}} \mathrm{Mann}-\mathrm{Whitney}$ 's $\mathrm{U}$ test comparing the age groups for patients, and ${ }^{\mathrm{c}}$ controls.

NP-PR1934 (98.4\%) compared with nonlabeled NP-CA2009 $(80.3 \%)(p=0.00098)$ similar to what was observed in the controls as nonlabeled NP-PR1934 displaced $97.5 \%$ compared with $79.5 \%$ with nonlabeled NP-CA2009 ( $p=2.9 \mathrm{e}-06$, Table 3 and Fig. 3B).
Maximal displacement (\%) did not differ between patients and controls for ${ }^{35}$ S-NP-CA2009 displacement with either nonlabeled NP-CA2009 $(p=0.81)$ or nonlabeled NP-PR1934 $(p=0.33)$, or ${ }^{35}$ S-NP-PR1934 displacement with nonlabeled NP-CA2009 $(p=0.64)$ or

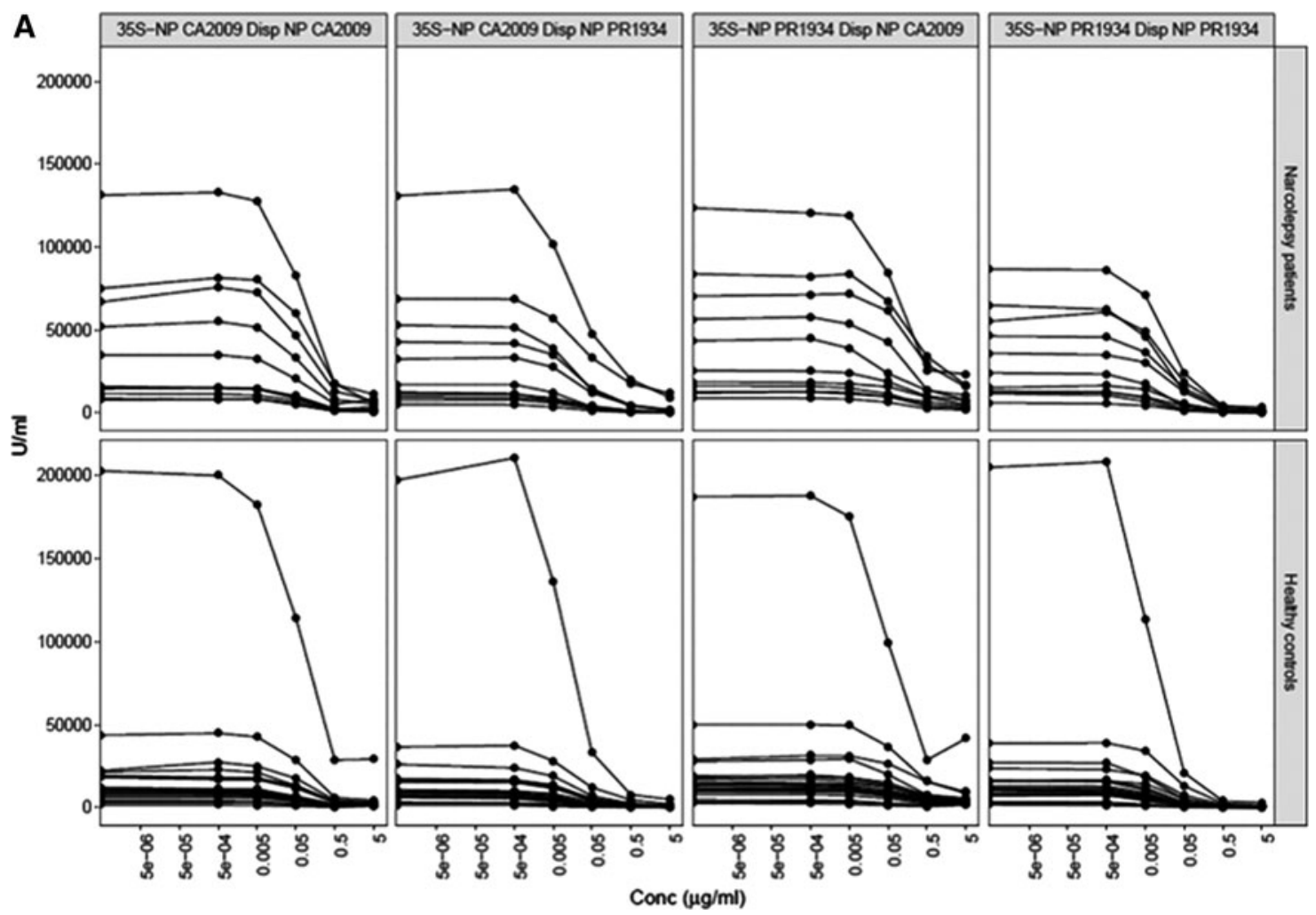

FIG. 3. (A) Un-normalized displacement curves. Serum samples from childhood narcolepsy patients $(n=11)$ and childhood controls $(n=21)$ were selected for subsequent displacement experiments to determine antibody affinity toward influenza A virus [A/ California/04/2009(H1N1)] nucleoprotein and toward influenza A virus [A/Puerto Rico/8/1934(H1N1)] nucleoprotein, respectively. (B) Fitted curves. Measure points are fitted to a four-parameter log-logistic function using the R-package drc. Maximal displacement (\%) for NP-CA2009 was compared when using nonlabeled NP-CA2009 (90.3\%) or nonlabeled NP-PR1934 (95.0\%) for the patients $(p=0.15)$ and for the controls (nonlabeled NP CA2009: 90.7\%; nonlabeled NP PR1934: 95.6\%, $p=0.01)$. Maximal displacement $(\%)$ for NP-PR1934 differed when using nonlabeled NP-CA2009 $(80.3 \%)$ compared with nonlabeled NP-PR1934 (98.4\%) for the patients $(p=0.00098)$ and for the controls (nonlabeled NP-CA2009: 79.5\%; nonlabeled NP-PR1934: 97.5\%, $p=2.9 \mathrm{e}-06)$. Maximal displacement $(\%)$ did not differ between patients and controls for NP-CA2009 displacement (nonlabeled NP-CA2009, $p=0.81$; nonlabeled NP-PR1934, $p=0.33$ ) or NP-PR1934 displacement (nonlabeled NP-CA2009, $p=0.64$; nonlabeled NP-PR1934, $p=0.97)$. (C) Nucleoprotein antibody affinities, Kd50. Note that the $y$-axis has different scales in the four panels. The median Kd50 value for NP-CA2009 displacement was compared when using nonlabeled NP-CA2009 (74 ng/mL) or nonlabeled NP-PR1934 $(23 \mathrm{ng} / \mathrm{mL})$ for the patients $(p=0.00098)$ and for the controls (nonlabeled NP-CA2009: $64 \mathrm{ng} / \mathrm{mL} ; \mathrm{NP}-\mathrm{PR} 1934: 14 \mathrm{ng} / \mathrm{mL}, p=9.5 \mathrm{e}-$ 07). The median Kd50 value for NP-PR1934 displacement was compared when using nonlabeled nucleoprotein NP-CA2009 $(199 \mathrm{ng} / \mathrm{mL})$ or nonlabeled NP-PR1934 $(20 \mathrm{ng} / \mathrm{mL})$ for the patients $(p=0.00098)$ and for the controls (nonlabeled NP CA2009: $165 \mathrm{ng} / \mathrm{mL}$; NP PR1934: $9 \mathrm{ng} / \mathrm{mL}, p=9.5 \mathrm{e}-07)$. The median Kd50 values were compared between patients and controls for NPCA2009 displacement (nonlabeled NP-CA2009, $p=0.21$; nonlabeled NP-PR1934, $p=0.0048$ ) and for NP-PR1934 displacement (nonlabeled NP-CA2009, $p=0.48$; nonlabeled NP-PR1934, $p=0.0031$ ). 


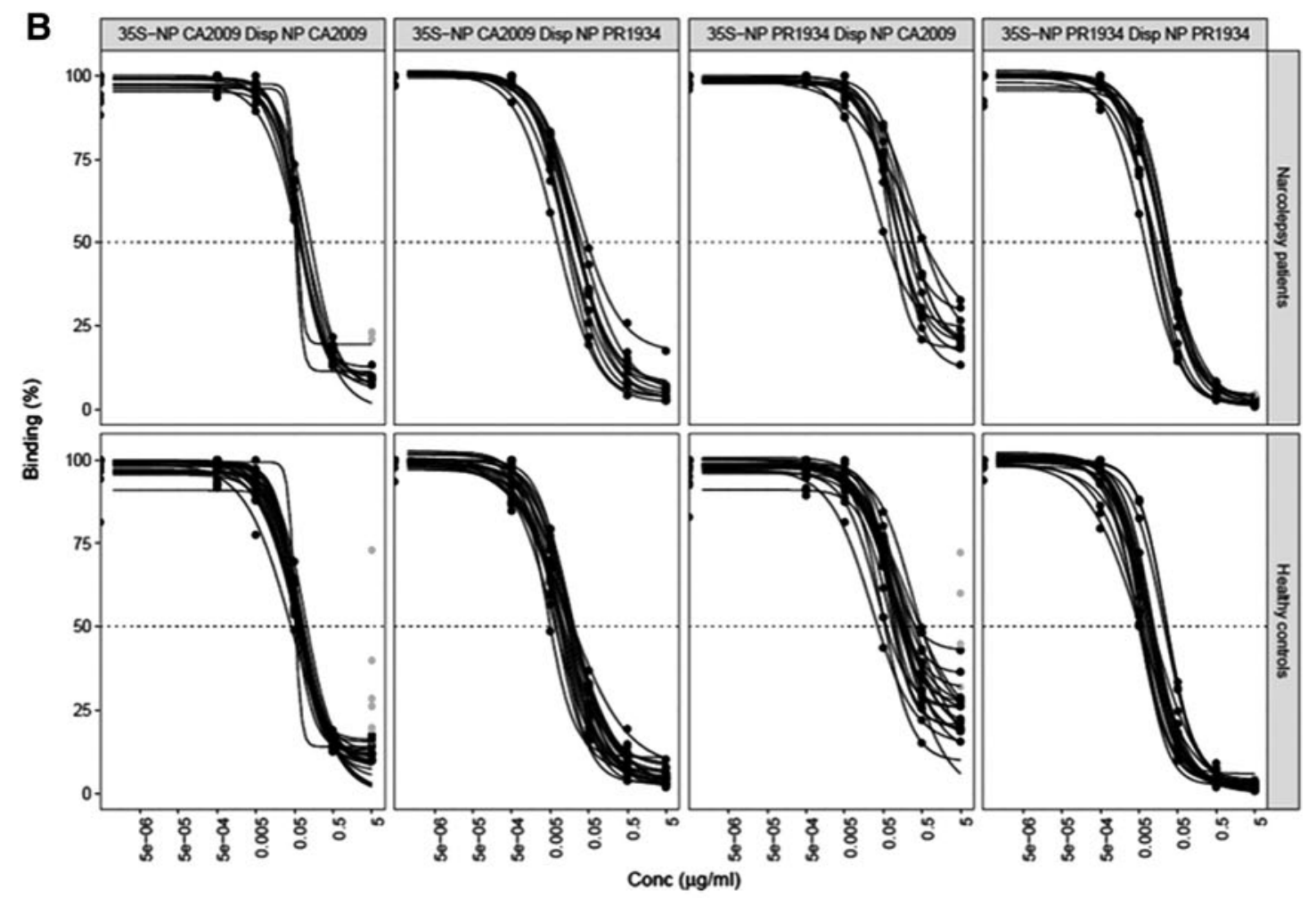

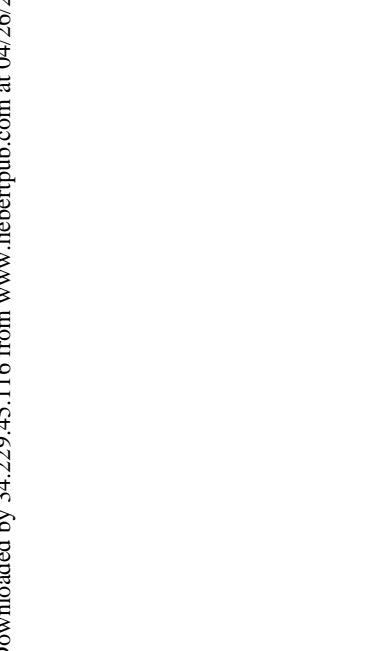

C

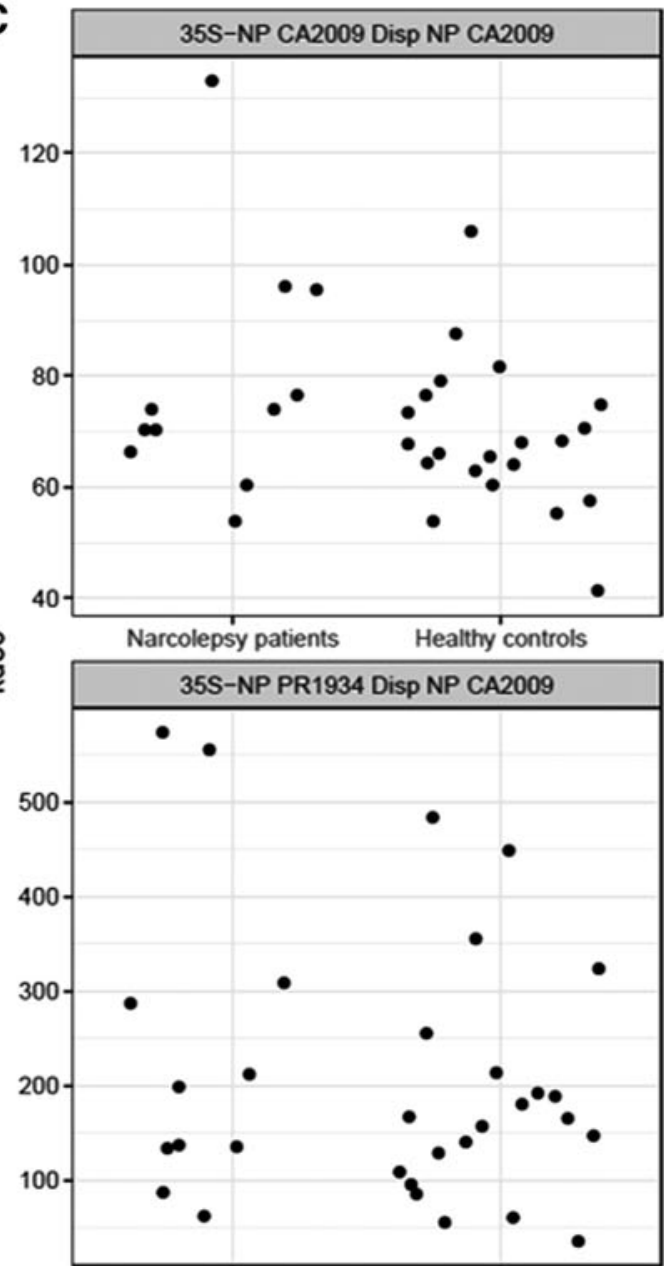

Narcolepsy patients

Healthy controls

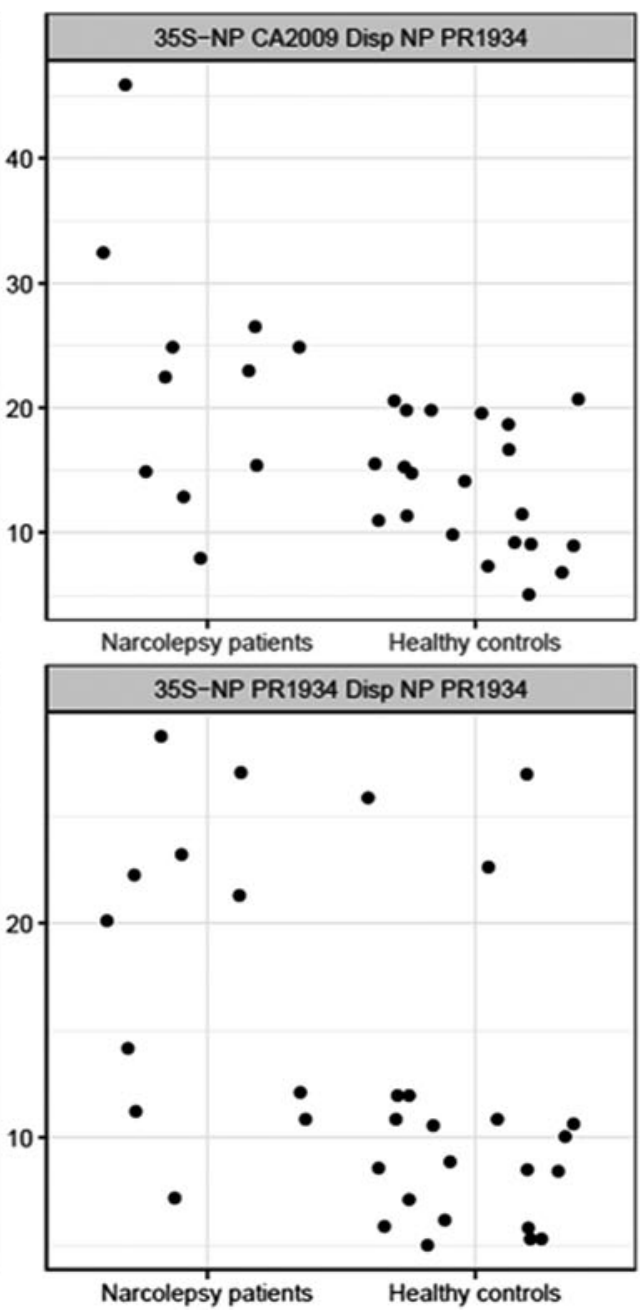

FIG. 3. (Continued). 
Table 3. Maximal Displacement Percentage and Kd50

\begin{tabular}{|c|c|c|c|c|c|c|c|}
\hline & & & CA2009, \% & PR1934, \% & $\mathrm{p}^{\mathrm{a}}$ & $\mathrm{p}^{\mathrm{b}}$ & $\mathrm{p}^{\mathrm{c}}$ \\
\hline s35-NP CA2009 & Maximal displacement & Patients & $90.3(80.4-100)$ & $95.0(82.9-97.9)$ & 0.15 & 0.81 & 0.33 \\
\hline s5-NP CA2009 & Maximal displacement & Controls & $90.7(83.8-100)$ & $95.6(89.1-99.1)$ & 0.01 & & \\
\hline $\mathrm{s}_{35-N P}$ PR1934 & Maximal displacement & Patients & $80.3(71.5-88.1)$ & $98.4(95.6-99.0)$ & 0.00098 & 0.64 & 0.97 \\
\hline \multirow[t]{2}{*}{ s35-NP PR1934 } & Maximal displacement & Controls & $79.5(57.3-100)$ & $97.5(94.1-100)$ & $2.9 \mathrm{e}-06$ & & \\
\hline & & & $C A 2009, n g / m L$ & $P R 1934, n g / m L$ & $\mathrm{p}^{\mathrm{a}}$ & $\mathrm{p}^{\mathrm{b}}$ & $\mathrm{p}^{\mathrm{c}}$ \\
\hline $\mathrm{s}_{35-N P}$ CA2009 & Kd50 & Patients & $74(54-133)$ & $23(8-46)$ & 0.00098 & 0.21 & 0.0048 \\
\hline${ }^{\mathrm{S}} 35-\mathrm{NP}$ CA2009 & Kd50 & Controls & $68(41-106)$ & $14(5-21)$ & $9.5 \mathrm{e}-07$ & & \\
\hline s5-NP PR1934 & Kd50 & Patients & $199(62-572)$ & $20(7-29)$ & 0.00098 & 0.48 & 0.0031 \\
\hline s35-NP PR1934 & Kd50 & Controls & $165(36-484)$ & $9(5-27)$ & $9.5 e-07$ & & \\
\hline
\end{tabular}

Median and range of Kd50 and maximal displacement percentage (computed from the fitted four-parameter log-logistic curves) values for patient and control samples.

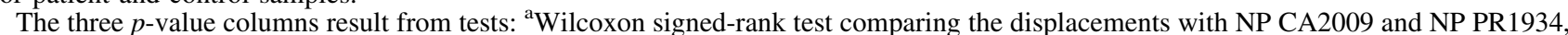

${ }^{b}$ Mann-Whitney U test comparing median values for patients and controls in the displacements with NP CA2009, and ${ }^{\mathrm{c}}$ NP PR1934.

$\mathrm{NP}$, nucleocapsid protein.

nonlabeled NP-PR1934 ( $p=0.97$, Table 3 and Fig. 3B), respectively.

Affinity. Affinity, expressed in $\mathrm{ng} / \mathrm{mL}$ as the inversed measurement of half-maximum binding ( $\mathrm{Kd} 50)$, was compared between patients and controls in reciprocal permutation (Fig. 3C).

First, the affinity of NP-CA2009 antibodies against ${ }^{35} \mathrm{~S}-\mathrm{NP}-\mathrm{CA} 2009$ was similar in the patients $(74 \mathrm{ng} / \mathrm{mL})$ compared with the controls $(68 \mathrm{ng} / \mathrm{mL} ; p=0.21)$.

Second, the affinity of NP-PR1934 antibodies against ${ }^{35} \mathrm{~S}-\mathrm{NP}$ CA2009 was lower $(23 \mathrm{ng} / \mathrm{mL})$ in the patients compared with the controls $(14 \mathrm{ng} / \mathrm{mL} ; p=0.0048)$.
Third, the affinity of NP-CA2009 antibodies against ${ }^{35} \mathrm{~S}-\mathrm{NP}-\mathrm{PR} 1934$ did not differ between patients $(199 \mathrm{ng} / \mathrm{mL})$ and controls $(165 \mathrm{ng} / \mathrm{mL} ; p=0.48)$.

However, fourth, the affinity of NP-PR1934 antibodies against ${ }^{35}$ S-NP-PR 1934 was reduced in the patients $(20 \mathrm{ng} /$ $\mathrm{mL})$ compared with the controls $(9 \mathrm{ng} / \mathrm{mL}, p=0.0031$, Table 3 and Fig. 3C).

The affinity was different for NP-CA2009 antibodies compared with NP-PR1934 antibodies against ${ }^{35}$ S-NP-CA2009 for the patients $(p=0.00098)$ as well as for the controls $(p=9.5 \mathrm{e}$ 07). Affinity was different for NP-CA2009 antibodies compared with NP-PR1934 antibodies against ${ }^{35}$ S-NP-PR1934 for the patients $(p=0.00098)$ and the controls $(p=9.5 \mathrm{e}-07)$.
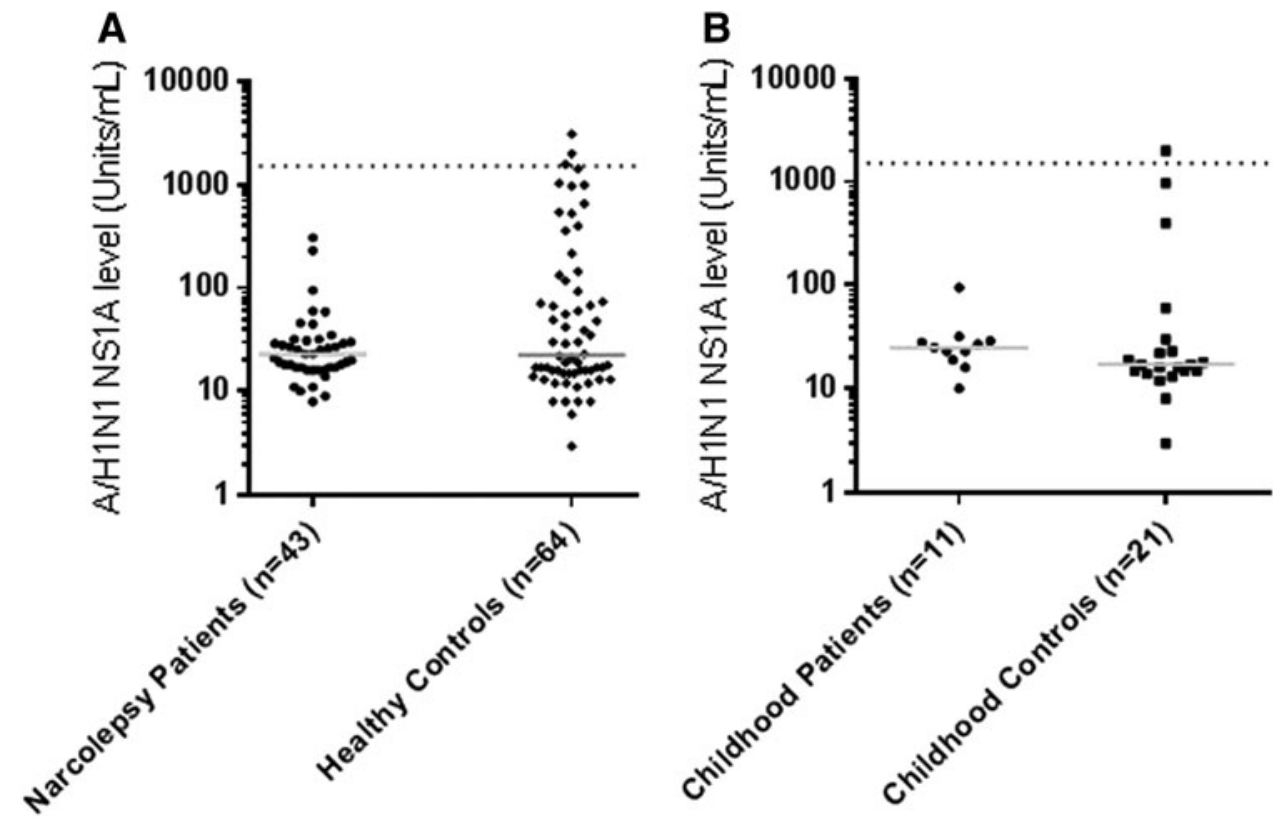

FIG. 4. (A) Median influenza A virus [A/California/04/2009(H1N1)] nonstructural protein (NSI) antibody levels were determined as $23(8-308) \mathrm{U} / \mathrm{mL}$ for 43 narcolepsy patients and $23(3-3,097) \mathrm{U} / \mathrm{mL}$ for 64 healthy controls. $(p=0.399)$. Zero of three $(0 \%)$ of the patients compared with 3/64 $(5 \%)$ of the healthy controls were considered positive for H1N1 NS1 antibodies $(p=0.272)$. (B) Median NS1 antibody levels were determined as $25(10-95) \mathrm{U} / \mathrm{mL}$ for 11 childhood patients compared with $17(3-1,999) \mathrm{U} / \mathrm{mL}$ for 21 healthy childhood controls $(p=0.123)$. Zero of twelve $(0 \%)$ of the patients compared with $1 / 21(5 \%)$ of the healthy childhood controls were considered positive for H1N1 NS1 antibodies. 
Nucleoprotein antibodies in relation to H1N1 HA antibodies and $\mathrm{HLA}$ DQB1 ${ }^{\star} 06: 02$ association

NP-CA2009 and NP-PR1934 antibodies correlated strongly for patients $(\rho=0.936, p<2.2 \mathrm{e}-16)$ and controls $(\rho=0.962$, $p<2$.2e-16, Supplementary Table S2). There was no association between the levels of the two different NP antibodies and previously reported H1N1 HA antibody levels (27) (Supplementary Table S2). No association was found between the levels of either NP antibody and HLA DQB1*06:02 (Supplementary Table S3).

\section{A/H1N1 nonstructural protein antibodies}

Median antibody binding level toward influenza A virus [A/California/04/2009(H1N1)] nonstructural protein (NSI) was $23(8-308) \mathrm{U} / \mathrm{mL}$ in the 43 narcolepsy patients compared with $23(3-3,097) \mathrm{U} / \mathrm{mL}$ for 64 healthy controls $(p=0.399$, Fig. 4A). Using the 97.25th percentile of 200 blood donors ascertained in 2008 as controls for a cutoff, it was found that $0 \%(0 / 43)$ in the patient group and $4.7 \%(3 / 64)$ in the healthy control group were considered positive for H1N1 NS1 antibodies $(p=0.272)$.

In the 11-childhood patient subgroup, the median NS1 antibody binding level was 25 (10-95) U/mL compared with $17(3-1,999) \mathrm{U} / \mathrm{mL}$ in the subgroup of 21 healthy childhood controls $(p=0.123$, Fig. 4B). Using the 97.5 th percentile of the blood donors, $0 \%(0 / 12)$ in the patient group compared with $4.8 \%$ (1/21) among the healthy childhood controls was considered positive for H1N1 NS1 antibodies.

\section{Discussion}

In the present study, we determined antibody levels toward both wild-type A/H1N1 2009[A/California/04/ 2009(H1N1)] (NP-CA2009) and Pandemrix [A/Puerto Rico/ 8/1934(H1N1)] (NP-PR1934) nucleoproteins in narcolepsy patients and age-matched controls. The major finding was that childhood patients had a lower antibody affinity against NP-PR1934 compared with healthy, childhood Pandemrixvaccinated controls. It was also noted that antibody affinities in childhood patients and controls were higher against NP-PR1934 than NP-CA2009. Our observation that none of the narcolepsy patients were positive for A/H1N1 NS1 antibodies indicates that they may not have been exposed to the H1N1 virus.

The affinity analysis was restricted to childhood patients not only primarily because they had higher levels of antibodies against HA2009 (27), NP-CA2009, and NP-PR1934 but also because childhood age at onset was unique to the Pandemrixassociated onset of narcolepsy $(4,37,39,41,45)$. It is noteworthy that the association between antibody levels and age was only positive for NP-PR1934 among the controls. Previous studies of antibody levels in relation to the 2009 influenza pandemic found an age-dependent variation, with higher levels of crossreactive antibodies among the elderly $(16,19,30)$.

The higher antibody affinity toward the Pandemrixassociated NP-PR1934 compared with influenza pandemic NP-CA2009 is remarkable given the high similarity in the amino acid sequence between the two nucleoproteins (Supplementary Fig. S1A). A cross-reactivity of antibodies (29) has most probably occurred, as indicated by the strong correlation in antibody levels between the nucleoproteins as well as with the commercially obtained polyclonal antibody to- ward NP PR1934 that also reacted with NP CA2009 (Supplementary Fig. S1B).

We report a lower NP-PR1934-specific affinity for young patients despite the higher NP antibody levels compared with healthy controls. Our results suggest that the vaccine-associated nucleoprotein had a stronger ability to evoke an immune response. This reaction might have been unexpected as the primary reason for switching NP-CA2009 for NP-PR1934 was to increase the yield of the vaccine (43). It can therefore not be excluded that the resulting hybrid virus contributed to an unwanted immune response that may have triggered narcolepsy.

The question regarding whether the 2009 influenza H1N1 pandemic contributed to narcolepsy is contentious; reports of increased incidence of nonvaccine-associated narcolepsy have emerged from China $(14,15)$. This is opposite to findings from European studies, which report no indication of wild-type A/H1N1 2009 infection as a prerequisite for narcolepsy (31). It is therefore possible that childhood narcolepsy following vaccination was related to the absence of previous influenza exposure (16).

We therefore speculate that the patients had no history of previous H1N1 exposure. The absence of prior crossreactive $\mathrm{H} 1 \mathrm{~N} 1$ antibodies would explain the vigorous immune response against NP-PR1934 compared with NPCA2009. However, the vigorous immune response resulted primarily in low-affinity NP antibodies, which might have been associated with the ability to generate broadly neutralizing influenza antibodies. Low-level neutralizing antibodies might allow prolonged exposure to the wild-type A/ H1N1 2009[A/California/04/2009(H1N1] virus and consequent damage to the hypocretin neurons.

Narcolepsy has been associated with Pandemrix (2) used in Europe $(34,37)$, but not with Arepanrix ${ }^{\circledR}(1,51)$ used in Canada and South America (35). Both vaccines were developed through a reassortment approach $(23,24,43)$; coinfection in eggs of wild-type and donor strains was followed by selection of a high-growth reassortant strain with antigenic characteristics of the wild-type virus. The new $\mathrm{A} /$ reassortant/NYMC X-179A (NYMC X-157×A/California/ 07/2009) influenza strain was selected with HA, NA, and PB1 genes from A/California/07/2009 (H1N1v) and the viral M, NP, NS, and PB2 genes from A/PR/8/34 (52).

Pandemrix and Arepanrix included both the AS03 adjuvants, but the use of detergents such as Polysorbate 80 and Triton X-100 in Pandemrix may have modified in vitro antigenic epitopes (50). Different purification and isolation protocols (Fluarix process-Pandemrix; Flulaval processArepanrix) were used at different manufacturing locations (Pandemrix; GSK, Dresden, Germany, and Arepanrix; GSK, Quebec, Canada) and whether these have resulted in antigenic differences are contentious $(7,20,43,50)$.

Differences in the association of narcolepsy with Pandemrix (Europe) and Arepanrix (Canada) pandemic influenza vaccines are speculated to involve viral antigenicity $(20,50)$. Efforts to measure the amount of NP have identified differences in the amount of NP antigen in each of these vaccines, which along with the lower prevalence of the narcolepsy risk allele $H L A D Q B 1: 0602$ in Canada, in part, may explain differences in postvaccination appearance of narcolepsy with these two vaccines. In addition, the influenza nucleoproteins in the wild-type A/H1N1 2009 pandemic and Pandemrix vaccine were different (50). 
Studies investigating the 1918 influenza pandemic suggest that the fatality could be due to the own immune system perhaps causing a cytokine storm (36), therefore affecting younger healthy individuals (47). The etiology of idiopathic narcolepsy is not known. Whether it can be linked to virusinduced disease in the brain as in experimental mice (48) or to alternative trigger mechanisms remains to be determined. Different trigger mechanisms may explain the epidemiological data from China suggesting an increased incidence of narcolepsy during the 2009 pandemic $(14,15)$.

In the present study, we did not observe that NP antibody levels were related to $H L A D Q B 1 * 06: 02$ (Supplementary Table S2). Although this would seem to be in contrast to recent studies suggesting that nucleoprotein antibody levels $(3,50)$ were related to $D Q B 1^{*} 06: 02$, it should be noted that our study of influenza A virus [A/California/04/2009/(H1N1)] HA antibody levels showed an association with $D Q B 1 * 06: 02$ (27). A potential weakness of the present study was that samples were not available from all subjects in the original case-control study (25). It would be of interest to further analyze virus protein affinities in an extended group of narcolepsy patients and controls. It is noted that NP-PR1934 is not specific for the Pandemrix vaccine, but that it is commonly used in H1N1 vaccine production $(23,43)$.

It is currently not explained how NP CA2009 and NP PR1934 antibody levels and affinity correlate with development of narcolepsy following Pandemrix vaccination. Further research is needed also to include analyses of antibody levels and affinities in adults. It is important to note that Pandemrix-induced narcolepsy primarily affects children, therefore this group were selected for this study.

In conclusion, an altered immune response among childhood narcolepsy patients toward influenza nucleoproteins is reported in the present study. Our data suggest increased antibody levels, but lower NP antibody affinity in the patients compared with controls. The final immunological mechanisms connecting Pandemrix to narcolepsy remain elusive, but the present study warrants further studies of antibody affinities that should be focused on the H1N1 viral protein components of the vaccine.

\section{Acknowledgments}

The authors thank the Lund University Medical Faculty for support and acknowledge the Swedish Medical Products Agency for the collection of blood samples. The study was supported by Filip Lundbergs stiftelse, Fredrik och Ingrid Thurings Stiftelse, Gunvor och Josef Anérs stiftelse, Kronprinsessan Lovisas Förening För Barnasjukvård/Stiftelsen Axel Tielmans Minnesfond, Linnéa och Josef Carlssons Stiftelse, Neuro Sweden, Rune Ljungdahls Stiftelse, the Segerfalk Foundation, Stiftelsen Samariten, Stiftelsen till minne av Personalföreningarna i Holmia Försäkring $\mathrm{AB}$, and Stohnes Stiftelse.

\section{Author Disclosure Statement}

No competing financial interests exist

\section{References}

1. Agency EM. Assessment report for Arepanrix. www.ema .europa.eu/docs/en_GB/document_library/EPAR_-_Public_ assessment_report/human/001201/WC500089740.pdf (last accessed on April 19, 2017).
2. Agency EM. Summary of product characteristicsPandemrix. 2010. www.ema.europa.eu/docs/en_GB/document library/EPAR_-_Product_Information/human/000832/ WC500038121.pdf (last accessed on April 19, 2017).

3. Ahmed SS, Volkmuth W, Duca J, et al. Antibodies to influenza nucleoprotein cross-react with human hypocretin receptor 2. Sci Transl Med 2015;7:294ra105.

4. Alakuijala A, Sarkanen T, and Partinen M. Polysomnographic and actigraphic characteristics of patients with H1N1-vaccine-related and sporadic narcolepsy. Sleep Med 2015;16:39-44.

5. Ambati A, Poiret T, Svahn BM, et al. Increased betahaemolytic group A streptococcal M6 serotype and streptodornase B-specific cellular immune responses in Swedish narcolepsy cases. J Intern Med 2015;278:264-276.

6. Aran A, Lin L, Nevsimalova S, et al. Elevated antistreptococcal antibodies in patients with recent narcolepsy onset. Sleep 2009;32:979-983.

7. Canelle Q, Dewé W, Innis BL, et al. Evaluation of potential immunogenicity differences between Pandemrix ${ }^{\mathrm{TM}}$ and Arepanrix $^{\mathrm{TM}}$. Hum Vaccin Immunother 2016;12:2289-2298.

8. Dauvilliers Y, Arnulf I, Lecendreux M, et al. Increased risk of narcolepsy in children and adults after pandemic H1N1 vaccination in France. Brain 2013;136:2486-2496.

9. Dauvilliers Y, Arnulf I, and Mignot E. Narcolepsy with cataplexy. Lancet 2007;369:499-511.

10. Dauvilliers Y, Siegel JM, Lopez R, et al. Cataplexyclinical aspects, pathophysiology and management strategy. Nat Rev Neurol 2014;10:386-395.

11. de Lecea L, Kilduff TS, Peyron C, et al. The hypocretins: hypothalamus-specific peptides with neuroexcitatory activity. Proc Natl Acad Sci U S A 1998;95:322-327.

12. Grubin CE, Daniels $\mathrm{T}$, Toivola B, et al. A novel radioligand binding assay to determine diagnostic accuracy of isoformspecific glutamic acid decarboxylase antibodies in childhood IDDM. Diabetologia 1994;37:344-350.

13. Han F, Faraco J, Dong XS, et al. Genome wide analysis of narcolepsy in China implicates novel immune loci and reveals changes in association prior to versus after the 2009 H1N1 influenza pandemic. PLoS Genet 2013;9:e1003880.

14. Han F, Lin L, Li J, et al. Decreased incidence of childhood narcolepsy 2 years after the 2009 H1N1 winter flu pandemic. Ann Neurol 2013;73:560.

15. Han F, Lin L, Warby SC, et al. Narcolepsy onset is seasonal and increased following the $2009 \mathrm{H} 1 \mathrm{~N} 1$ pandemic in china. Ann Neurol 2011;70:410-417.

16. Hancock K, Veguilla V, Lu X, et al. Cross-reactive antibody responses to the 2009 pandemic H1N1 influenza virus. N Engl J Med 2009;361:1945-1952.

17. Hedstrom AK, Bomfim IL, Barcellos LF, et al. Interaction between passive smoking and two HLA genes with regard to multiple sclerosis risk. Int J Epidemiol 2014;43:17911798.

18. Heier MS, Gautvik KM, Wannag E, et al. Incidence of narcolepsy in Norwegian children and adolescents after vaccination against H1N1 influenza A. Sleep Med 2013;14: 867-871.

19. Itoh $\mathrm{Y}$, Shinya K, Kiso M, et al. In vitro and in vivo characterization of new swine-origin H1N1 influenza viruses. Nature 2009;460:1021-1025.

20. Jacob L, Leib R, Ollila HM, et al. Comparison of Pandemrix and Arepanrix, two pH1N1 AS03-adjuvanted vaccines differentially associated with narcolepsy development. Brain Behav Immun 2015;47:44-57. 
21. Johansson J, Becker C, Persson NG, et al. C-peptide in dried blood spots. Scand J Clin Lab Invest 2010;70:404-409.

22. Juji T, Satake M, Honda Y, et al. HLA antigens in Japanese patients with narcolepsy. All the patients were DR2 positive. Tissue Antigens 1984;24:316-319.

23. Kilbourne ED. Future influenza vaccines and the use of genetic recombinants. Bull World Health Organ 1969;41: 643-645.

24. Kilbourne ED, Schulman JL, Schild GC, et al. Correlated studies of a recombinant influenza-virus vaccine. I. Derivation and characterization of virus and vaccine. J Infect Dis 1971;124:449-462.

25. Lamb F, Ploner A, Fink K, et al. No Evidence for disease history as a risk factor for narcolepsy after A(H1N1)pdm09 vaccination. PloS One 2016;11:e0154296.

26. Liblau RS, Vassalli A, Seifinejad A, et al. Hypocretin (orexin) biology and the pathophysiology of narcolepsy with cataplexy. Lancet Neurol 2015;14:318-328.

27. Lind A, Ramelius A, Olsson T, et al. A/H1N1 antibodies and TRIB2 autoantibodies in narcolepsy patients diagnosed in conjunction with the Pandemrix vaccination campaign in Sweden 2009-2010. J Autoimmun 2014;50:99-106.

28. Link J, Kockum I, Lorentzen AR, et al. Importance of human leukocyte antigen (HLA) class I and II alleles on the risk of multiple sclerosis. PloS One 2012;7:e36779.

29. Mandelboim M, Bromberg M, Sherbany H, et al. Significant cross reactive antibodies to influenza virus in adults and children during a period of marked antigenic drift. BMC Infect Dis 2014;14:346.

30. Manicassamy B, Medina RA, Hai R, et al. Protection of mice against lethal challenge with $2009 \mathrm{H} 1 \mathrm{~N} 1$ influenza A virus by 1918 -like and classical swine H1N1 based vaccines. PLoS Pathog 2010;6:e1000745.

31. Melen K, Partinen M, Tynell J, et al. No serological evidence of influenza A H1N1pdm09 virus infection as a contributing factor in childhood narcolepsy after Pandemrix vaccination campaign in Finland. PloS One 2013;8:e68402.

32. Mignot E. Genetic and familial aspects of narcolepsy. Neurology 1998;50:S16-S22.

33. Mignot E, Lin L, Rogers W, et al. Complex HLA-DR and DQ interactions confer risk of narcolepsy-cataplexy in three ethnic groups. Am J Hum Genet 2001;68:686-699.

34. Miller E, Andrews N, Stellitano L, et al. Risk of narcolepsy in children and young people receiving AS03 adjuvanted pandemic A/H1N1 2009 influenza vaccine: retrospective analysis. Br Med J 2013;346:f794.

35. Montplaisir J, Petit D, Quinn MJ, et al. Risk of narcolepsy associated with inactivated adjuvanted (AS03) A/H1N1 (2009) pandemic influenza vaccine in Quebec. PloS One 2014;9:e108489.

36. Morens DM, and Fauci AS. The 1918 influenza pandemic: insights for the 21st century. J Infect Dis 2007;195:10181028.

37. Nohynek H, Jokinen J, Partinen M, et al. AS03 adjuvanted AH1N1 vaccine associated with an abrupt increase in the incidence of childhood narcolepsy in Finland. PloS One 2012; 7:e33536.

38. Partinen M, Kornum BR, Plazzi G, et al. Narcolepsy as an autoimmune disease: the role of $\mathrm{H} 1 \mathrm{~N} 1$ infection and vaccination. Lancet Neurol 2014;13:600-613.

39. Partinen M, Saarenpaa-Heikkila O, Ilveskoski I, et al. Increased incidence and clinical picture of childhood narcolepsy following the $2009 \mathrm{H} 1 \mathrm{~N} 1$ pandemic vaccination campaign in Finland. PloS One 2012;7:e33723.

40. Persson I, Granath F, Askling J, et al. Risks of neurological and immune-related diseases, including narcolepsy, after vaccination with Pandemrix: a population- and registrybased cohort study with over 2 years of follow-up. J Intern Med 2014;275:172-190.

41. Pizza F, Peltola H, Sarkanen T, et al. Childhood narcolepsy with cataplexy: comparison between post-H1N1 vaccination and sporadic cases. Sleep Med 2014;15:262-265.

42. Ritz C, and Streibig JC. Bioassay analysis using R. J Stat Softw 2005;12:1-22.

43. Robertson JS, Nicolson C, Harvey R, et al. The development of vaccine viruses against pandemic $\mathrm{A}(\mathrm{H} 1 \mathrm{~N} 1)$ influenza. Vaccine 2011;29:1836-1843.

44. Skarstrand H, Krupinska E, Haataja TJ, et al. Zinc transporter 8 (ZnT8) autoantibody epitope specificity and affinity examined with recombinant $\mathrm{ZnT}$ 8 variant proteins in specific ZnT8R and ZnT8W autoantibody-positive type 1 diabetes patients. Clin Exp Immunol 2015;179:220-229.

45. Szakacs A, Darin N, and Hallbook T. Increased childhood incidence of narcolepsy in western Sweden after H1N1 influenza vaccination. Neurology 2013;80:1315-1321.

46. Tafti M, Hor H, Dauvilliers Y, et al. DQB1 locus alone explains most of the risk and protection in narcolepsy with cataplexy in Europe. Sleep 2014;37:19-25.

47. Taubenberger JK, and Morens DM. 1918 Influenza: the mother of all pandemics. Emerg Infect Dis 2006;12:15-22.

48. Tesoriero C, Codita A, Zhang MD, et al. H1N1 influenza virus induces narcolepsy-like sleep disruption and targets sleep-wake regulatory neurons in mice. Proc Natl Acad Sci U S A 2016;113:E368-E377.

49. Thannickal TC, Moore RY, Nienhuis R, et al. Reduced number of hypocretin neurons in human narcolepsy. Neuron 2000;27:469-474.

50. Vaarala O, Vuorela A, Partinen M, et al. Antigenic differences between AS03 adjuvanted influenza A (H1N1) pandemic vaccines: implications for Pandemrix-associated narcolepsy risk. PloS One 2014;9:e114361.

51. GlaxoSmithKline Inc. Product information leaflet: Arepanrix ${ }^{\mathrm{TM}}$ H1N1. AS03-adjusted H1N1 pandemic influenza vaccine, April 20, 2010. http://www.hc-sc.gc.ca/dhp-mps/alt_formats/ pdf/prodpharma/legislation/interimorders-arretesurgence/ prodinfo-vaccin-eng.pdf (last accessed on April 18, 2017).

52. World Health Organization (WHO). WHO biosafety risk assessment and guidelines for the production and quality control of human influenza pandemic vaccines: Update. http://www .who.int/biologicals/areas/vaccines/influenza/CP116_20092107_Biosafety_pandemicA_H1N1_flu_vaccines-AddendumDRAFTFINAL.pdf (last accessed on April 18, 2017).

Address correspondence to: Alexander Lind, MSc

Department of Clinical Sciences Lund University/Clinical Research Center (CRC) Skåne University Hospital SUS Malmö Jan Waldenströms gata 35 SE-205 02 Malmö Sweden

E-mail: alexander.lind@med.lu.se 